\title{
A REVIEW OF CARDIOPULMONARY RESEARCH IN BRAZILIAN MEDICAL JOURNALS: CLINICAL, SURGICAL AND EPIDEMIOLOGICAL DATA
}

\author{
Carlos Serrano, Mauricio Rocha e Silva
}

doi: $10.1590 / \mathrm{S} 1807-59322010000400014$

Serrano C, Rocha-e-Silva M. A review of cardiopulmonary research in brazilian medical journals: clinical, surgical and epidemiological data. Clinics. 2010;65(4):441-5.

Research in the field of cardiopulmonary disease in Brazil has been very active in recent decades. The combination of PUBMED, SCieLO, open access and online searching has provided a significant increase in the visibility of Brazilian journals. This newly acquired international visibility has in turn resulted in the appearance of more original research reports in the Brazilian scientific press. This review is intended to highlight part of this work for the benefit of the readers of "Clinics." We searched through PUBMED for noteworthy articles published in Brazilian medical journals included in the Journal of Citation Reports of the Institute of Scientific Information to better expose them to our readership. The following journals were examined: "Arquivos Brasileiros de Cardiologia," "Arquivos Brasileiros de Endocrinologia e Metabologia," "Brazilian Journal of Medical and Biological Reviews," "Jornal Brasileiro de Pneumologia," "Jornal de Pediatria," "Revista Brasileira de Cirurgia Cardiovascular," "Revista da Associação Médica Brasileira," Revista da Escola de Enfermagem U.S.P." and "São Paulo Medical Journal." These journals publish original investigations in the field of cardiopulmonary disease. The search produced 71 references, which are briefly examined.

KEYWORDS: Cardiology; Pneumology; Clinical research; Surgery; Epidemiology.

\section{INTRODUCTION}

Research in the field of cardiopulmonary disease in Brazil has been very dynamic over recent decades. The combination of PUBMED, SCieLO, open access and internet searching has led to an increase in the visibility of Brazilian scientific journals. This in turn has produced a significant proportion of original research reports into the Brazilian scientific press with this newly acquired international visibility.

This review is intended to highlight some of these studies for the benefit of the readers of CLINICS. We have therefore searched through PUBMED for significant articles in the field of cardiopulmonary disease published in Brazilian journals and included in the Journal of Citation Reports of the Institute of Scientific Information to better expose them to our readers.

Hospital das Clinicas, Faculdade de Medicina da Universidade de São Paulo - São Paulo/SP, Brazil.

Tel.: 55113069.6235

Email: mrsilva36@hcnet.usp.br

Received for publication on March 15, 2010

First review completed on April 01, 2010

Accepted for publication on April 05, 2010

\section{METHODS}

An online search was conducted through PUBMED for articles published in Brazilian journals on cardiopulmonary research that are indexed in the Journal of Citation Reports of the Institute for Scientific Information. The following journals were examined: "Arquivos Brasileiros de Cardiologia," "Arquivos Brasileiros de Endocrinologia e Metabologia," "Brazilian Journal of Medical and Biological Reviews," "Jornal Brasileiro de Pneumologia," "Jornal de Pediatria," "Revista Brasileira de Cirurgia Cardiovascular," "Revista da Associação Médica Brasileira," Revista da Escola de Enfermagem U.S.P." and "São Paulo Medical Journal." Most of the articles reviewed were published in 2009. This search produced a total of 71 articles, which were divided into four categories: clinical cardiology, cardiac surgery, pneumology and epidemiology. The articles are summarized under these headings.

Clinical cardiology. The importance of exercise for cardiac function was addressed by investigators who reported on the safety of the six-minute walk-test for heart 
transplantation candidates (Cipriano et al) $)^{1}$ and on left ventricular systolic function (Berisha et al.). ${ }^{2}$ The circulatory response to a 50-meter walk in acute coronary syndrome was presented by Dias et al. ${ }^{3}$ Furtado et al. reported on blood pressure measurements during aerobic exercise in cardiac rehabilitation, ${ }^{4}$ whereas Oliveira et al. reported on the effect of the walk test on the length of hospital stay for cardiac surgery patients. ${ }^{5}$ The relationships between fitness, waist circumference and hypertension in elderly Brazilian women were investigated by Krause et al. ${ }^{6}$ Pelegrino et al. studied the influence of lean body mass on cardiopulmonary repercussions during the six-minute walk test in patients with chronic obstructive pulmonary disease (COPD). ${ }^{7}$

Coronary disease was covered in four reports. Silvério et al. conducted a gender-specific evaluation of coronary disease patients' self-esteem and social support. ${ }^{8}$ Barbirato studied the use of resting myocardial scintigraphy during chest pain to exclude the diagnosis of acute myocardial infarction. ${ }^{9}$ Pesaro et al. investigated the effects of leukocytes and glycemia on the prognosis of patients with acute myocardial infarction. ${ }^{10}$ Finally, Santos et al. evaluated a new risk score for non-ST-segment elevation acute coronary syndrome. ${ }^{11}$

Heart failure was discussed in five different papers. Del Carlo et al. described the relevance of cardiac troponin $\mathrm{T}$ for risk stratification. ${ }^{12}$ Santos analyzed the quality of life in this group of patients..$^{13}$ Savioli et al. examined the importance of angiotensin-converting enzyme inhibitors and plasma B-type natriuretic peptide levels in elderly patients with heart failure ${ }^{14}$ while Munhoz correlated microneurography and venous occlusion plethysmography with prognosis. ${ }^{15}$ Margoto et al. examined the clinical and psychosocial features of heart failure patients admitted for clinical decompensation. ${ }^{16}$

The use of echocardiography as a diagnostic tool was discussed in two papers. Cury et al. addressed its safety, ${ }^{17}$ and Vieira et al. assessed its utility for measuring left ventricular ejection fraction. ${ }^{18}$

Aidar et al. analyzed the effect of sleep apnea on the heart rates of COPD patients. ${ }^{19}$ Arteaga analyzed the prognostic value of the collagen volume fraction in hypertrophic cardiomyopathy. ${ }^{20}$ Atik described the clinical progress of patients with small ventricular septal defects. ${ }^{21}$ Costa et al. showed that body mass index has a good correlation with proatherosclerotic profile in children and adolescents. ${ }^{22} \mathrm{Sa}$ et al. described the effects of conventional ventricular stimulation on patients with normal ventricular function. ${ }^{23}$ Barbaro and Silva discussed the cardiovascular complications in acquired immunodeficiency syndrome. ${ }^{24}$

The interaction of diabetes and hypertension was the subject of Silva et al., who examined the relevance of abdominal fat and insulin resistance to arterial hypertension in non-obese patients, ${ }^{25}$ of Cobas et al., who described the development of type 1 diabetes into hypertension, ${ }^{26}$ and of Rosa et al., who analyzed the effects of antihypertensive drugs in obese women. ${ }^{27}$

Cardiac surgery. This topic was the subject of 16 original publications. Sadala et al. described their experience with heart transplantation in patients with Chagas' disease. ${ }^{28}$ Rocha and Silva et al. analyzed the outcome of surgical mitral valve repair in children with rheumatic fever. ${ }^{29}$ Santana Filho evaluated patients undergoing mitral valve replacement with crossed papillopexy with echocardiography. ${ }^{30}$ Salerno et al. described the results of beating heart mitral valve surgery via the trans-septal approach. ${ }^{31}$ Dalva et al. described initial results of intermittent annular reduction with Alfieri's repair for the treatment of mitral insufficiency in children. ${ }^{32} \mathrm{~A}$ midterm follow up of patients undergoing mitral and aortic valve replacement with the St. Jude Medical valve was the subject of a study by Rodrigues et al., ${ }^{33}$ while De Bacco et al. discussed risk factors for hospital mortality in valve replacement with a mechanical prosthesis. ${ }^{34}$

Coronary artery bypass surgery was the topic of four separate studies: Atik et al. described indications for and results of the use of the axillary artery for cardiopulmonary bypass. ${ }^{35}$ Brito et al. surveyed risk factors for the development of acute renal failure following cardiopulmonary bypass. ${ }^{36}$ Silva et al. examined late angiographic grafting patency in patients with recurrent symptoms,${ }^{37}$ while Piegas et al. described the results of myocardial revascularization surgery (MRS) in the national health system. ${ }^{38}$ We also tracked an interesting study by Avila et al. on maternal and fetal prognosis as well as outcome of cardiac surgery during pregnancy. ${ }^{39}$ Geovanni analyzed the use of chemoprophylaxis for atrial fibrillation following cardiac surgery. ${ }^{40}$ Helito et al. discussed quality of life in heart transplant candidates. ${ }^{41}$ Tirapelli et al. described the occurrence of apoptosis in human saphenous vein grafts in the restoration of blood flow through coronary bypass surgery. ${ }^{42}$ Vieira et al. analyzed the hydrodynamic profiles of different roller pumps models used for cardiopulmonary bypass. ${ }^{43}$

Pneumology. This field was covered in 16 original research articles. Exercise was again the most frequent theme. Ferreira et al. analyzed respiratory rehabilitation in COPD in the transition from exercise training to real life. ${ }^{44}$ Pelegrino et al. examined the influence of lean body mass on cardiopulmonary repercussions during the six-minute walk test in patients with COPD. ${ }^{7}$ Ziegler et al. looked at predictors of oxygen desaturation during the six-minute 
walk test in patients with cystic fibrosis. ${ }^{45}$ Oliveira et al. reviewed the relationships between the walk test, pulmonary function tests and length of hospitalization in cardiac surgery patients. ${ }^{5}$ Bertolace et al. studied the association between obesity and asthma among teenagers. ${ }^{46}$ Simões et al. assessed the prevalence of reduced respiratory muscle strength in institutionalized elderly people. ${ }^{47}$ Sleep desaturation and its influence on arterial pressure in COPD patients were the subjects of a study by Aidar et al. ${ }^{19}$ Malbouisson et al. showed that lung hyperinflation stimulates the release of inflammatory mediators in spontaneously breathing subjects. ${ }^{48}$

The association between nutritional status measurements and pulmonary function in children and adolescents with cystic fibrosis was analyzed by Chavez et al. ${ }^{49}$ Bandeira et al. demonstrated the prevalence of gastro-esophageal reflux disease in patients with idiopathic pulmonary fibrosis. ${ }^{50}$ Costa et al. described the role of inflammatory cells and their mediators in COPD pathogenesis ${ }^{51}$ Perrechi and Ribeiro surveyed the effort to integrate tuberculosis treatment between hospitals and public health care clinics in the city of Sao Paulo, Brazil. ${ }^{52}$ Cataneo et al. described the occurrence of active tuberculosis in surgical patients with negative preoperative sputum smear results. ${ }^{53}$ Parra et al. studied the occurrence of systemic sclerosis, idiopathic interstitial pneumonia and histomorphometric differences in lung biopsies. ${ }^{54}$

Epidemiological studies. The incidence of metabolic syndrome has been examined in multiple Brazilian studies. ${ }^{55-60}$ The prevalence of congenital heart disease in patients with Down's syndrome was reported ${ }^{61}$ Two different studies evaluated cardiovascular mortality in different parts of Brazil. ${ }^{62,63}$ The profile of newborns who underwent cardiac surgery in a private hospital in the city of Sao Paulo was described. ${ }^{64}$ Other studies examined diseases of the circulatory system, asthma, tuberculosis, hypertension and smoking in specific geographic settings. ${ }^{65-71}$

\section{REFERENCES}

1. Cipriano G, Jr., Yuri D, Bernardelli GF, Mair V, Buffolo E, Branco $\mathrm{JN}$. Analysis of 6-minute walk test safety in pre-heart transplantation patients. Arq Bras Cardiol. 2009;92(4):312-319.

2. Berisha V, Bajraktari G, Dobra D, Haliti E, Bajrami R, Elezi S. Echocardiography and 6-minute walk test in left ventricular systolic dysfunction. Arq Bras Cardiol. 2009;92(2):121-134.

3. Dias CM, Maiato AC, Baqueiro KM, Fiqueredo AM, Rosa FW, Pitanga $\mathrm{JO}$, et al. Circulatory response to a 50-m walk in the coronary care unit in acute coronary syndrome. Arq Bras Cardiol. 2009;92(2):128-142.

4. Furtado EC, Ramos Pdos S, Araujo CG. Blood pressure measurement during aerobic exercise: subsidies for cardiac rehabilitation. Arq Bras Cardiol. 2009;93(1):45-52.

5. Oliveira EK, Silva VZ, Turquetto AL. [Relationship on walk test and pulmonary function tests with the length of hospitalization in cardiac surgery patients.]. Rev Bras Cir Cardiovasc. 2009;24(4):478-484.

6. Krause MP, Hallage T, Gama MP, Miculis CP, Matuda Nda S, Silva SG. Association of fitness and waist circumference with hypertension in Brazilian elderly women. Arq Bras Cardiol. 2009;93(1):2-8 .

7. Pelegrino NR, Lucheta PA, Sanchez FF, Faganello MM, Ferrari R, Godoy I. Influence of lean body mass on cardiopulmonary repercussions during the six-minute walk test in patients with COPD. J Bras Pneumol. 2009;35(1):20-26.

8. Silverio CD, Dantas RA, Carvalho AR. [Gender-specific evaluation of coronary disease patients' self-esteem and social support]. Rev Esc Enferm USP. 2009;43(2):407-414.

9. Barbirato GB, Azevedo JC, Felix RC, Correa PL, Volschan A, Viegas $\mathrm{M}$, et al. Use of resting myocardial scintigraphy during chest pain to exclude diagnosis of acute myocardial infarction. Arq Bras Cardiol. 2009;92(4):269-274.
10. Pesaro AE, Nicolau JC, Serrano CV, Jr., Truffa R, Gaz MV, Karbstein R, et al. Influence of leukocytes and glycemia on the prognosis of patients with acute myocardial infarction. Arq Bras Cardiol. 2009;92(2):84-93.

11. Santos ES, Timerman A, Baltar VT, Castillo MT, Pereira MP, Minuzzo $\mathrm{L}$, et al. Dante Pazzanese risk score for non-st-segment elevation acute coronary syndrome. Arq Bras Cardiol. 2009;93(4):343-351, 336-344.

12. Del Carlo CH, Pereira-Barretto AC, Cassaro-Strunz CM, Latorre Mdo R, Oliveira Junior MT, Ramires JA. Cardiac troponin T for risk stratification in decompensated chronic heart failure. Arq Bras Cardiol. 2009;92(5):372-380, 389-397, 404-312.

13. Santos JJ, Plewka JE, Brofman PR. Quality of life and clinical indicators in heart failure: a multivariate analysis. Arq Bras Cardiol. 2009;93(2):159-166.

14. Savioli Neto F, Magalhaes HM, Batlouni M, Piegas LS. ACE inhibitors and plasma B-type natriuretic peptide levels in elderly patients with heart failure. Arq Bras Cardiol. 2009;92(5):320-326, 336-343, 349-356.

15. Munhoz RT, Negrao CE, Barretto AC, Ochiai ME, Cardoso JN, Morgado $\mathrm{PC}$, et al. Microneurography and venous occlusion plethysmography in heart failure: correlation with prognosis. Arq Bras Cardiol. 2009;92(1):46-53.

16. Margoto G, Colombo RC, Gallani MC. [Clinical and psycosocial features of heart failure patients admitted for clinical decompensation]. Rev Esc Enferm USP. 2009;43(1):44-53.

17. Cury AF, Vieira ML, Fischer CH, Rodrigues AC, Cordovil A, Monaco C, et al. Safety of transesophageal echocardiography in adults: study in a multidisciplinary hospital. Arq Bras Cardiol. 2009;93(5):478-483.

18. Vieira ML, Nomura CH, Tranchesi Junior B, Oliveira WA, Naccarato $\mathrm{G}$, Serpa BS, et al. Left ventricular ejection fraction and volumes as measured by $3 \mathrm{~d}$ echocardiography and ultrafast computed tomography. Arq Bras Cardiol. 2009;92(4):294-301. 
19. Aidar NA, Silva MA, Melo e Silva CA, Ferreira Junior PN, Tavares P. ABPM in COPD patients with sleep desaturation. Arq Bras Cardiol. 2009;93(3):275-282.

20. Arteaga E, de Araujo AQ, Bernstein M, Ramires FJ, Ianni BM, Fernandes $\mathrm{F}$, et al. Prognostic value of the collagen volume fraction in hypertrophic cardiomyopathy. Arq Bras Cardiol. 2009;92(3):210-214, 216-220.

21. Atik E. Small ventricular septal defect: long-term expectant clinical management. Arq Bras Cardiol. 2009;92(6):396-399, 413-396, 429-332.

22. Costa GB, Horta N, Resende ZF, Souza G, Barreto LM, Correia LH, et al. Body mass index has a good correlation with proatherosclerotic profile in children and adolescents. Arq Bras Cardiol. 2009;93(3):261267.

23. Sa LA, Rassi S, Batista MA. Conventional ventricular stimulation effects on patients with normal ventricular function. Arq Bras Cardiol. 2009;93(2):167-173.

24. Barbaro G, Silva EF. Cardiovascular complications in the acquired immunodeficiency syndrome. Rev Assoc Med Bras. 2009;55(5):621630

25. Silva EA, Flexa F, Zanella MT. Impact of abdominal fat and insulin resistance on arterial hypertension in non-obese women. Arq Bras Endocrinol Metabol. 2009;53(3):340-343

26. Cobas R, Santos B, Braga L, Cunha EF, Gomes MB. [Type 1 diabetic patients evolution to hypertension]. Arq Bras Endocrinol Metabol. 2008;52(4):628-634.

27. Rosa EC, Zanella MT, Kohlmann NE, Ferreira SR, Plavnik FL, Ribeiro $\mathrm{AB}$, et al. Blood pressure and cardiorenal responses to antihypertensive therapy in obese women. Arq Bras Endocrinol Metabol. 2008;52(1):6575 .

28. Sadala ML, Stolf NA, Bicudo MA. [Heart transplantation: the experience of patients with Chagas disease]. Rev Esc Enferm USP. 2009;43(3):588595

29. Rocha e Silva A, Herdy GV, Vieira AA, Simoes LC. Surgical mitral valve repair in children with rheumatic fever. Arq Bras Cardiol. 2009;92(6):400-404, 417-421, 433-408.

30. Santana Filho GP, Gomes OM, Oliveira GJ, Rodrigues D, Nogueira AC, Sales R, et al. Echocardiographic evaluation of patients undergoing mitral valve replacement with crossed papillopexy. Arq Bras Cardiol. 2009;93(2):92-96.

31. Salerno TA, Suarez M, Panos AL, Macedo FI, Alba J, Brown M, et al. Results of beating heart mitral valve surgery via the trans-septal approach. Rev Bras Cir Cardiovasc. 2009;24(1):4-10.

32. Dalva M, Bichara GC, Cunha Filho CE, Carneiro GF, Saliba GN, Camacho JA, et al. Intermittent annular reduction with Alfieri's repair in the treatment of mitral insufficiency in children: initial results. Rev Bras Cir Cardiovasc. 2009;24(3):354-358.

33. Rodrigues AJ, Evora PR, Bassetto S, Alves L, Jr., Scorzoni Filho A, Vicente WV. Isolated mitral and aortic valve replacement with the St. Jude Medical valve: a midterm follow-up. Arq Bras Cardiol. 2009;93(3):290-298.

34. De Bacco MW, Sartori AP, Sant'Anna JR, Santos MF, Prates PR, Kalil RA, et al. Risk factors for hospital mortality in valve replacement with mechanical prosthesis. Rev Bras Cir Cardiovasc. 2009;24(3):334-340.
35. Atik FA, Faber CN, Corso RB, Santos Mde S, Michelette KP, Barros MR, et al. Axillary artery in cardiopulmonary bypass: indications and results. Rev Bras Cir Cardiovasc. 2009;24(3):404-408.

36. Brito DJ, Nina VJ, Nina RV, de Figueiredo Neto JA, de Oliveira MI, Salgado JV, et al. Prevalence and risk factors for acute renal failure in the postoperative of coronary artery bypass grafting. Rev Bras Cir Cardiovasc. 2009;24(3):297-304.

37. Silva RR, Truffa MA, Birolli JR, Silva TF, De Mola R, Oliveira JB. $\mathrm{CABG}$ late angiographic grafting patency analysis in patients with recurrent symptoms. Rev Bras Cir Cardiovasc. 2009;24(2):138-142.

38. Piegas LS, Bittar OJ, Haddad N. Myocardial revascularization surgery (MRS): results from national health system (SUS). Arq Bras Cardiol. 2009;93(5):555-560

39. Avila WS, Gouveia AM, Pomerantzeff P, Bortolotto MR, Grinberg M, Stolf N, et al. Maternal-fetal outcome and prognosis of cardiac surgery during pregnancy. Arq Bras Cardiol. 2009;93(1):9-14.

40. Geovanini GR, Alves RJ, Brito G, Miguel GA, Glauser VA, Nakiri K. Postoperative atrial fibrillation after cardiac surgery: who should receive chemoprophylaxis? Arq Bras Cardiol. 2009;92(4):326-330.

41. Helito RA, Branco JN, D’Innocenzo M, Machado RC, Buffolo E. Quality of life in heart transplant candidates. Rev Bras Cir Cardiovasc. 2009;24(1):50-57.

42. Tirapelli LF, Tirapelli DP, Dalio MB, Rodrigues AJ, Evora PR Expression of apoptosis in human saphenous vein grafts in restoration of blood flow through coronary bypass surgery. Rev Bras Cir Cardiovasc. 2009;24(3):312-317

43. Vieira FU, Jr., Vieira RW, Antunes N, Petrucci O, Oliveira PP, Serra MM, et al. Analysis of the hydrodynamic profile in different roller pumps models used in cardiopulmonary bypass. Rev Bras Cir Cardiovasc. 2009;24(2):188-193

44. Ferreira SA, Guimaraes M, Taveira N. Pulmonary rehabilitation in COPD: from exercise training to 'real life'. J Bras Pneumol. 2009;35(11):1112-1115.

45. Ziegler B, Rovedder PM, Oliveira CL, Schuh SJ, Silva FA, Dalcin Pde T. Predictors of oxygen desaturation during the six-minute walk test in patients with cystic fibrosis. J Bras Pneumol. 2009;35(10):957-965.

46. Bertolace Mdo P, Toledo E, Jorge PP, Liberatore Junior Rdel R. Association between obesity and asthma among teenagers. Sao Paulo Med J. 2008;126(5):285-287.

47. Simoes RP, Castello V, Auad MA, Dionisio J, Mazzonetto M. Prevalence of reduced respiratory muscle strength in institutionalized elderly people. Sao Paulo Med J. 2009;127(2):78-83

48. Malbouisson LM, Szeles TF, Barbalho L, Massoco CO, Carmona MJ, Carvalho CR, et al. Lung hyperinflation stimulates the release of inflammatory mediators in spontaneously breathing subjects. Braz $\mathrm{J}$ Med Biol Res.43(2):201-205.

49. Chaves CR, Britto JA, Oliveira CQ, Gomes MM, Cunha AL. Association between nutritional status measurements and pulmonary function in children and adolescents with cystic fibrosis. J Bras Pneumol. 2009;35(5):409-414.

50. Bandeira CD, Rubin AS, Cardoso PF, Moreira Jda S, Machado Mda M Prevalence of gastroesophageal reflux disease in patients with idiopathic pulmonary fibrosis. J Bras Pneumol. 2009;35(12):1182-1189. 
51. Costa CH, Rufino R, Lapa ESJR. [Inflammatory cells and their mediators in COPD pathogenesis]. Rev Assoc Med Bras. 2009;55(3):347-354.

52. Perrechi MC, Ribeiro SA. Tuberculosis treatment: integration between hospitals and public health care clinics in the city of Sao Paulo, Brazil. J Bras Pneumol. 2009;35(11):1100-1106.

53. Cataneo DC, Ruiz RL, Jr., Cataneo AJ. Active tuberculosis in surgical patients with negative preoperative sputum smear results. J Bras Pneumol. 2009;35(9):892-898.

54. Parra ER, Otani LH, de Carvalho EF, Ab'Saber A, Capelozzi VL. Systemic sclerosis and idiopathic interstitial pneumonia: histomorphometric differences in lung biopsies. J Bras Pneumol. 2009;35(6):529-540.

55. Almeida RT, Almeida MM, Araujo TM. Abdominal obesity and cardiovascular risk: performance of anthropometric indexes in women. Arq Bras Cardiol. 2009;92(5):345-350, 362-347, 375-380.

56. Bopp M, Barbiero S. Prevalence of metabolic syndrome in outpatients of the institute of cardiology of Rio Grande do Sul. Arq Bras Cardiol. 2009;93(5):473-477.

57. Franco GP, Scala LC, Alves CJ, de Franca GV, Cassanelli T, Jardim PC. Metabolic syndrome in patients with high blood pressure in CuiabaMato Grosso State: prevalence and associated factors. Arq Bras Cardiol. 2009;92(6):437-442, 456-461, 472-438.

58. Pereira A, Guedes AD, Verreschi IT, Santos RD, Martinez TL. Obesity and its association with other cardiovascular risk factors in school children in Itapetininga, Brazil. Arq Bras Cardiol. 2009;93(3):253-260.

59. Ribas SA, da Silva LC. Dyslipidemia in schoolchildren from private schools in Belem. Arq Bras Cardiol. 2009;92(6):412-417, 429-434, 446-451.

60. Brollo L, Bombig MT, Mazzaro Cdo L, Francisco YA, Fonseca FA, Carvalho AC, et al. Relationship between electrocardiogram with diabetes mellitus and metabolic syndrome in Japanese-Brazilians. Arq Bras Cardiol. 2009;92(5):351-355, 381-356.

61. Nisli K. Prevalence of congenital heart defects in patients with Down's syndrome. J Pediatr (Rio J). 2009;85(5):377-378.
62. Farias N, de Souza JM, Laurenti R, de Alencar SM. Cardiovascular mortality by gender and age range in the city of Sao Paulo, Brazil: 1996 to 1998, and 2003 to 2005. Arq Bras Cardiol. 2009;93(5):498-505.

63. Ferreira GM, Correia LC, Reis H, Ferreira Filho CB, Freitas F, Junior I, et al. Increased mortality and morbidity due to acute myocardial infarction in a public hospital, in Feira de Santana, Bahia. Arq Bras Cardiol. 2009;93(2):97-104.

64. Bueno M, Kimura AF. [Profile of newborns who underwent cardiac surgery in a private hospital in the city of Sao Paulo]. Rev Esc Enferm USP. 2008;42(1):112-119.

65. Carvalho BG, Souza RK, Soares DA, Yagi MC. [Diseases of the circulatory system before and after the Family Health Program, Londrina, Parana]. Arq Bras Cardiol. 2009.

66. Brandao HV, Cruz CS, Pinheiro MC, Costa EA, Guimaraes A, SouzaMachado A, et al. Risk factors for ER visits due to asthma exacerbations in patients enrolled in a program for the control of asthma and allergie rhinitis in Feira de Santana, Brazil. J Bras Pneumol. 2009;35(12):11681173.

67. Cantalice Filho JP. Food baskets given to tuberculosis patients at a primary health care clinic in the city of Duque de Caxias, Brazil: effect on treatment outcomes. J Bras Pneumol. 2009;35(10):992-997.

68. Coelho AG, Zamarioli LA, Perandones CA, Cuntiere I, Waldman EA. Characteristics of pulmonary tuberculosis in a hyperendemic area: the city of Santos, Brasil. J Bras Pneumol. 2009;35(10):998-1007.

69. Desalu OO, Adekoya AO, Elegbede AO, Dosunmu A, Kolawole TF, Nwogu KC. Knowledge of and practices related to smoking cessation among physicians in Nigeria. J Bras Pneumol. 2009;35(12):1198-1203.

70. Rosa AM, Ignotti E, Hacon Sde S, Castro HA. Prevalence of asthma in children and adolescents in a city in the Brazilian Amazon region. $\mathrm{J}$ Bras Pneumol. 2009;35(1):7-13.

71. Nascente FM, Jardim PC, Peixoto Mdo R, Monego ET, Barroso WK, Moreira HG, et al. [Hypertension and its association to anthropometric indexes in adults from a small city ln Brazil.]. Rev Assoc Med Bras. 2009;55(6):716-722. 